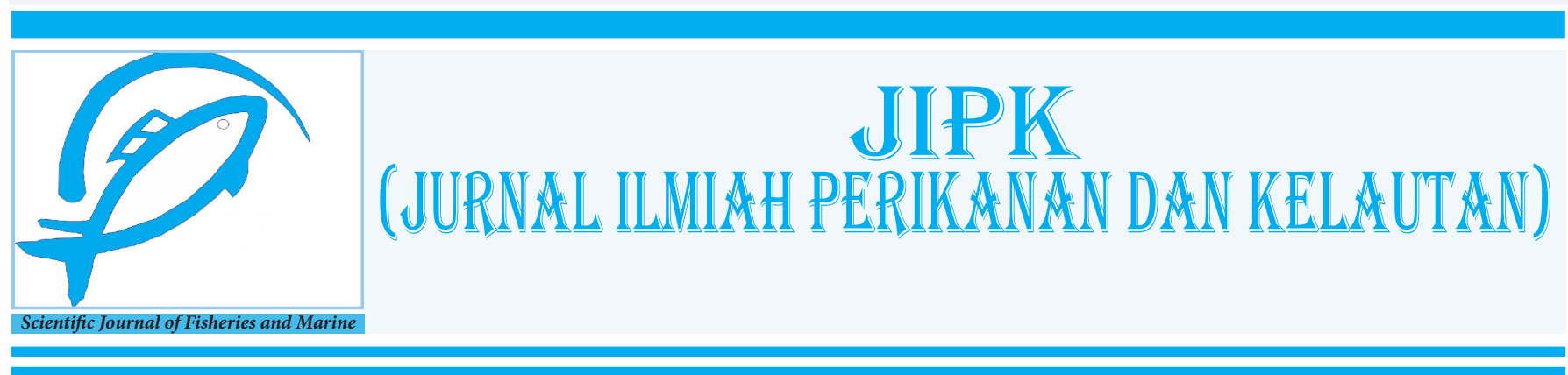

Review Article

\title{
A Review on Puerulus (Panulirus spp.) Resource Utilization in Indonesia Based on the Sense of Hearing: Auditory Receptor Organs
}

\author{
Hari Subagio $^{1 *}$ (D), Evron Asrial ${ }^{2}$, Yusnaini ${ }^{3}$, Nurul Rosana ${ }^{1}$, Gatut Bintoro ${ }^{4}$, Nuhman ${ }^{1}$, and I Made \\ Kawan $^{5}$
}

${ }^{1}$ Department of Fisheries, Faculty of Engineering and Marine Science, Hang Tuah University, Surabaya. Indonesia ${ }^{2}$ Department of Fisheries Resources Utilization, Faculty of Fishery, University 45 Mataram, Nusa Tenggara Barat. Indonesia ${ }^{3}$ Department of Aquaculture, Faculty of Fishery and Marine Science, Halu Oleo University, Kendari. Indonesia ${ }^{4}$ Department of Fisheries Resources Utilization, Faculty of Fisheries and Marine Science, Brawijaya University, Malang. Indonesia ${ }^{5}$ Department of Aquatic Resources Management, Faculty of Agriculture, Warmadewa University, Denpasar. Indonesia

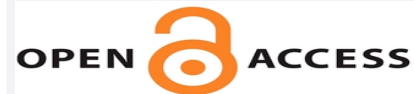

\section{$\underline{\text { ARTICLE INFO }}$}

Received: April 27, 2021

Accepted: August 20, 2021

Published: September 28, 2021

*) Corresponding author:

E-mail: hari.subagio@hangtuah. ac.id

Keywords:

Body Surface Receptors

Chordotonal Organs

Phonoreceptors

Sound Wave

Statocyst Organs

This is an open access article under the CC BY-NC-SA license (https://creativecommons.org/ licenses/by-nc-sa/4.0/)

\begin{abstract}
Indonesia is a country that produces abundant lobster seeds (puerulus), however, there is a dilemma, where natural mortality in the first year since entering the settlement phase can reach $96.0-99.4 \%$. The use of lobster resources especially in the puerulus stage for cultivation is very strategic. Therefore, it is necessary to improve puerulus fishing technology. In the capture fisheries sector, the use of the sense of hearing in fish resources has been carried out to increase catch productivity, by utilizing sound wave-based attractors' technology. For lobster resources, to what extent is this technology applicable? Underwater sound waves are a phenomenon of compression and expansion of a medium as sound energy passes through it. This aspect of the study is still new and very prospective. The purpose of this review article is to answer some basic questions: Are lobsters able to hear sounds that come from their surroundings, since when do lobsters sense of hearing begin to function, and anatomically what kind of auditory organs are in lobsters. The results of the review conclude as follows: lobsters have senses that are able to perceive or listen to sound waves (sound) from their surrounding environment, this ability has been possessed by lobsters since they were in the postlarva or puerulus stage. Anatomically, the organs that act as the sense of hearing in lobsters are: receptors on the body surface, chordotonal organs and statocyst organs.
\end{abstract}

Cite this as: Subagio, H., Asrial, E., Yusnaini, Rosana, N., Bintoro, G., Nuhman, \& Kawan, I. M. (2021). A Review on Puerulus (Panulirus spp.) Resource Utilization in Indonesia Based on the Sense of Hearing: Auditory Receptor Organs. Jurnal Ilmiah Perikanan dan Kelautan, 13(2):255-270. http://doi.org/10.20473/jipk.v13i2.26545 


\section{Introduction}

The harvesting of lobster resources can be done through fishing and cultivation activities (Indonesian Government, 2020), the activity of catching lobster seeds from the wild is again permitted, with certain conditions, after previously being banned by the government (Indonesian Government, 2016). This moment is very important for the reopening of lobster cultivation activities in Indonesia. With the program support from the Directorat General of Aquaculture, Marine and Fisheries Ministry, through the Lobster Cultivation Development Policy in Indonesia, it is estimated that the need for lobster seeds caught from nature will increase significantly because hatching technology for lobster resources has not been mastered (Susanti et al., 2017).

In terms of lobster seeds, Indonesia has a competitive advantage, both in terms of the abundance of natural puerulus resources (Priyambodo, 2020) as well as the suitability of its oceanographic and geographical conditions that allow for the existence of sustainable puerulus stocks (Jones, 2018). Indonesia has a great potential to develop as the center of the world's largest lobster aquaculture industry (Priyambodo, 2020). However, there is a problematic situation in lobster seeds, where the level of natural mortality is very high in the first year since entering the settlement phase, because predatory prey is very high, some researchers state that reaching around 80.0-96.0\% (Phillips, 2003), 95.999.4\% (Smith and Herrnkind, 1992), or 96.0-99.0\% (Herrnkind and Butler, 1994). In order to apply the concept of sustainable management of lobster resources, improvements in fishing technology are indeed needed (Evron, 2020). In this context of sustainable use, puerulus resource can basically be utilized more efficiently, for example, being captured and then cultivated (Jones, 2018; Jones et al., 2019; Jones et al., 2020). The use of puerulus resource was hoped to help us economically but in fact we experienced enormous economic loses instead (Husni et al., 2021). Indonesia is trying to apply the concept of a capture-based farming system to lobster resources, and is the only country in Southeast Asia to start lobster cultivation using natural puerulus supplies (Jones, 2010; Priyambodo and Jaya, 2009; Priyambodo and Sarifin, 2009).

So far, no technological solution has been applied to increase the survival rate and abundance of natural juvenile lobster. For this reason, it is hoped that the Indonesian Government will conduct a holistic study to prepare a strategic plan for lobster fisheries in an optimal and sustainable manner (Evron, 2020). In order to get optimal benefits from lobster resources, especially in the postlarvae stage, it can be done by means of appropriate fishing, as a strategic alternative solution, before being eaten by various predators (Phillips, 2003; Herrnkind and Butler, 1994; Smith and Herrnkind, 1992).

In capture fisheries, the use of the sense of hearing in fisheries resources, especially fish (Pisces), has been studied and has led to an applicative domain. The results of research on the application of sound wavebased attractors in gill net fishing gear are proven to be able to invite and increase the catch of 'bulu ayam' fish (Thryssa setirostris) (Rosana et al., 2018a; Rosana et al., 2018b; Rosana et al., 2019). In the context of sound wave-based attractor technology, there is a big question to what extent is the possibility of this tool being applied to lobster resources (Panulirus spp).

Until now, there have been many studies on the sense of hearing in lobsters (Lovell et al., 2005; Taylor and Patek, 2010; Edmonds et al., 2016). Recent research has shown that lobsters are capable of producing underwater sound vibrations that can be detected up to more than 3 kilometers away (Jézéquel et al., 2020). However, research on this aspect has not been intensive enough, especially those oriented to the utilization of the potential for the acoustic behavior of lobsters, in particular the development of sound wave based attractor technology in its utilization has not been carried out. This aspect of this study is new and very prospective. In order to optimize the use of sound wave-based attractor technology through fishing activities, of course, requires an understanding of the biological aspects and acoustic behavior of lobster resources. For this reason, the authors compile a review article related to the sense of hearing in lobsters, the plan is that the article is written in three aspects of the study; the auditory sense receptor organs in lobsters, the physiology of the auditory receptor organs in lobsters, and the utilization of acoustics by lobsters. In this first review article, the author aims to answer some fundamental questions: Can lobsters hear sounds coming from their surroundings, since when do lobsters' sense of hearing begin to function, and anatomically what kind of hearing organs are in lobsters.

\section{What does Hearing Mean?}

Hearing is a condition where organisms have the ability to be able to feel sound with the sense of hearing. Sound is a vibration that moves as an acoustic wave, through a variety of transmission media such as gas, liquid, and solid. Based on the point of view of the field of physiology and psychology, sound is a phenomenon in which the brain perceives the presence of sound waves like Lovell et al. (2005) who have proven 
the mechanism and hearing ability in shrimp (Palaemon serratus) with the Auditory Brainstem Response technique. Sound waves are characterized by the compression and expansion of the medium as sound energy travels through it. At the same time, there is also the back and forth motion of the particles that make up the medium (Hu et al., 2009).

The definition of receiving sound or hearing, especially in underwater habitats, is still controversial. When using the definition of hearing in a narrow sense, it is almost certain that the sense of hearing is not shared by most crustaceans, except for the fiddler crab and ghost crab (Salmon and Atsaides, 1968; Horch, 1975; Salmon, 1984). On the other hand, when referring to a broad definition, most crustaceans have the ability to hear because their receptor system allows them to receive sound waves originating from their environment. (Budelmann, 1992).

Underwater sound waves are closely related to the aspect of pressure oscillation and the substance of the vibration medium. Crustaceans that live in aquatic habitats are known to be sensitive to vibrations in the water (Breithaupt and Tautz, 1990). Does this indicate that crustaceans can hear sound waves? There are several kinds of understanding about hearing; some of them are based on the presence of the tympanic hearing organ, some depend on the level of acceptance of the sound pressure component, while others only cover the perception of water vibrations (Budelmann, 1992). However, the definition of hearing (the ability to hear) should include the calm perception of the ability to perceive sound waves produced by similar species, especially when the sound is produced using special organ structures. For example, various organs are capable of producing sound emission from different types of crustaceans (Schmitz, 2002) and when these sounds can be easily detected by other similar organisms (Winn and Hazlett, 1962; Atema and Voigt, 1995; Popper et al., 2001).

Basically marine invertebrates can hear underwater sounds although in a different way from vertebrates. It is thought that they can sense the presence of movement and vibrations associated with the process of producing underwater sound. Some of the oceanic invertebrates that are able to produce sound outside the water have specific sensory organs that can detect changes in acoustic pressure in the air. However, in invertebrates whose habitat is in the sea, this is done by detecting the presence of particle movement. In Cephalopods, the presence of sensory hairs on the outside and statocysts on the inside plays an important role in detecting sound
(Packard et al., 1990; Kaifu et al., 2008; Mooney et al., 2010). Lovell et al. (2005) further stated that lobsters can detect various kinds of vibrations resulting from underwater sounds. Mechanical stimuli, such as water movement, touch, and sound vibrations, are important aspects for the Panulirus argus in finding food and organisms of the same species, avoiding predators, maintaining balance and direction, controlling movement, and detecting vibrations (Wilkens et al., 1996).

\section{Acoustic Behavior on the Lobster}

Several types of lobsters from the genera Panulirus and Palinurus are known to produce sound in various ways and possibly able to detect the presence of underwater sound (Cohen and Dijkgraaf, 1961). Sound has the potential to serve as a form of intraspecific communication, but do crustaceans have a sense of hearing? Initially this became controversial even though in the end it was proven that crustaceans have the ability to detect sound waves (Patek, 2001; Lovell et al., 2005; Edmonds, 2016).

So far the lobsters that are known to be able to make sounds with their antennae when attacked or disturbed by predators are from the genus Panulirus. This behavior is shown by Panulirus longipes, the presence of the sound produced by the antenna was first detected at the postpuerulus stage, and while at the time the puerulus was planktonic it still did not produce sound (Meyer-Rochow and Penrose, 1974). Furthermore, Meyer-Rochow and Penrose (1976) reported that the second type of sound found is called "slow rattle", produced by lobsters that are older. P. longipes are able to perform phonoreception and this behavior is influenced by the presence of underwater sounds. Under certain conditions, lobsters also produce sound alerts about a state of danger (Meyer-Rochow et al., 1982). The Homarus americanus can also produce a sound similar to a clawing sound at a frequency of 100-300 Hz. This sound is produced with the help of the contraction of the sonic muscles located at the base of the second antenna (Atema and Voigt, 1995; Henninger and Watson, 2005).

Palinurid lobsters from the Stridentes group (George and Main, 1967) can produce sound with the help and performance of the stridulator organ which is anatomically located at the base of the second antenna (Patek, 2001; Patek, 2002). Unfortunately, the mechanism for producing this sound is not fully understood. It is suspected that the sound produced is used to deter potential predators. Lobster $P$. argus can also produce sound by whipping its antenna quickly when attacked by a triggerfish. This type of lobster does not have the 
ability to produce sound as an anti-predatory behavior, so lobsters tend to be more easily eaten by predators than other organisms equipped with good stridulator organs (Phillips, 2006).

\section{Lobster Hearing Ability}

The lobster life cycle is divided into several phases, namely eggs, nauplisoma, phyllosoma, puerulus (non-pigmented lobster seeds), and juvenile, which consists of yuwana and fingerling and adult stages (De Lara et al., 2005; Suastika et al., 2008; Thao, 2012). In the early life of lobsters, eggs hatch into nauplisoma, which lasts about 4-6 hours (Gilchrist, 1913), then turn into phyllosoma which are the wandering phase. Phyllosomas are planktonic and they exist in the open seas for 4-24 months (Booth and Phillips, 1994), depend on the type of species. Furthermore, Booth and Phillips (1994) stated that the duration of the phyllosoma phases for Panulirus elephas was 10-12 months, $P$. argus was more than 6 months, Panulirus cygnus was 9-11 months, Panulirus interruptus was 8 months, Panulirus penicillatus was 7-8 months, Panulirus homarus was 4-6 months, and Panulirus marginatus was 6-11 months. Meanwhile, for pearl lobster (Panulirus ornatus) the duration was 4-6 months (Smith et al., 2009). Maintenance of $P$. ornatus from the puerulus stage to maturity of gonads takes about 37 months (Yusnaini, 2010).

After entering the postlarva stage, puerulus migrate towards coastal waters. At this stage, lobsters already have organs that can detect underwater sound waves in the form of statocysts and chordotonal organs. It is thought that these organs play an important role in finding the location of coastal waters (Sekiguchi and Terazawa, 1997; Popper et al., 2001; Jeff et al., 2005), then enter the settlement phase in shallow waters on the coast (Phillips and Macmillan, 1987; Jeff et al., 2005; De Lara et al., 2005).

Studies on the mechanosensory of puerulus and juvenile antenna of several lobster species have proven the existence of a number of setae structures along the puerulus antenna flagella and early juvenile stages, but these structures were not found in the late phyllosoma stage (Macmillan et al., 1992; Jeffs et al., 1997). This shows that the ability of lobsters to detect mechanical stimuli from their environment begins when they are in the puerulus phase (Jeffs et al., 1997). Similar sensory setae structures are found in other decapods, which in their life cycle do not have a migration phase to coastal waters, but appear to have the ability to detect underwater mechanosensory at low frequencies (Ball and Cowan, 1977; Denton and Gray, 1985). In gener- al, marine arthropods are capable of producing sound with the characteristics of broadband pulses, e.g. short transient sounds of large bandwidth (Meyer-Rochow and Penrose, 1976; Au and Banks, 1998; Jézéquel et al., 2019).

Crustaceans have organs that function as underwater vibration receptors (Popper et al., 2001) which Meyer-Rochow et al. (1982) refers to as phonoreceptor organs. This organ plays an important role in receiving underwater sound waves. Budelmann (1992) and Breithaupt and Tautz (1990) classified these phonoreceptor organs into three groups, namely: the receptor system on the body surface, the chordotonal organ receptor system, and the statocyst receptor system.

\subsection{Receptor Systems on the Surface of the Body}

The receptor system on the surface of the body is also known as the superficial receptor system which functions to detect the presence of vibrations in water, otherwise known as the hydrodynamic receptor system. These receptors are found all over the body surface of many types of crustaceans (Budelmann, 1989). Each receptor system has a single hair cuticle (sensillum) or a group of hairs. Anatomically, these hairs have flexible basal joints and are mechanically linked to one to four sensory cells (Schone and Steinbrecht, 1968; Ball and Cowan, 1977; Vedel, 1985). Hair length varies depending on location, generally around 20-2,000 $\mu \mathrm{m}$ with various shapes (Bush and Laverack, 1982; Vedel, 1985). Hair can easily be bent by the movement of water, so that it will mechanically stimulate the sensory cells present (Derby, 1982).

The presence of hairs cuticles is clearly seen in Decapods, especially in lobsters and crayfish. They appear on the surface of the carapace (Laverack, 1963; Mellon, 1963) and all over the body (Laverack, 1962; Vedel and Clarac, 1976; Derby, 1982). These hairs appear to be numerous and have been well studied especially those on both the antenna and the antenula (Tazaki and Ohnishi, 1974; Tazaki, 1977; Phillips and Macmillan, 1987), the chelae (Laverack, 1963; Solon and Cobb, 1980; Tautz and Sandeman, 1980), and also on Telson (Wiese, 1976). Atema and Voigt (1995) stated that lobsters antenna are the main mechanosensory organ, but more broadly, lobsters actually have mechanoreceptor senses that function properly through direct or indirect contact. These senses are spread throughout the surface of their carapace, both externally and internal. Hair cuticle receptors are very sensitive to vibrations in water between $0.05-300 \mathrm{~Hz}$, depending on the species (Breithaupt and Tautz, 1990; 
Goodall et al., 1990; Wiese and Marschall, 1990).

The ability of lobsters to detect the presence of underwater vibrations will help the organism to sense the movement of other organisms around it. Researchers have found the presence of sensory hairs for underwater vibrations found in the dactylus of Cherax quadricarinatus, the optimal sensitivity of these sensory feathers to vibrations is at frequencies between 150-300 Hz (Tautz et al., 1981; Masters et al., 1982; Breithaupt and Tautz, 1990). Slightly different from what happened to the American lobster (H. americanus), the hair that acts as a sensory on the surface of the lobster's body is proven to be able to detect underwater sounds at low frequencies, namely 20-300 Hz (Derby, 1982; Factor, 1995).

The acoustic system in lobsters is basically related to the frequency and amplitude of sound waves originating from their environment as well as the presence of sound-producing organs and the sensitivity of the existing sense of hearing. The study of superficial receptors for detecting vibrations in water was carried out by Derby (1982). The study stated that mechanosensory and chemosensory nerves innervate all members of the cephalothorax of the $H$. americanus, including the antenna, antenula, six pairs of mouth parts, and five pairs of pereiopods.

Smooth and squamous setae type sensilla showed sensitivity to chemical and mechanical stimulation, which was physiologically indicated by the presence of a neural recording response during chemical and mechanical stimulation of the pereiopods which had all types of setae. Mechanoreceptor nerves in these setae are sensitive to treatment in the form of underwater vibrations or direct touch. Similar experiments on the Serrate setae type sensilla, that found in the third and fourth pereiopods proved that this type of setae has a function identical to that of the Smooth and squamous setae type. Hedgehog hairs type sensilla are sensitive to mechanical and chemical stimuli. Mechanoreceptor nerves associated with these hairs are very sensitive to bending and touch, but this type of sensilla cannot respond to water currents. The Peg sensilla responds to mechanical stimulation, but not to chemical stimuli. This indicates that the Peg sensilla only functions as a mechanoreceptor. Furthermore, Oakley and Macmillan (1980) stated that CAP organs type sensilla of Jasus novaehollandiae were shown only to respond to mechanical stimulation (Table 1).

Table 1. Sensilla in the pereiopod Homarus americanus (Derby, 1982)

\begin{tabular}{|c|c|c|c|c|}
\hline Type Sensilla & $\begin{array}{c}\text { Position on } \\
\text { Pereiopods } \\
\text { (1-5) }\end{array}$ & Location on the Pereiopods & $\begin{array}{l}\text { Length } \\
(\mu \mathrm{m})\end{array}$ & $\begin{array}{l}\text { Physiological fung- } \\
\text { tion }\end{array}$ \\
\hline $\begin{array}{l}\text { Smooth and Squa- } \\
\text { mous setae }\end{array}$ & $1-5$ & $\begin{array}{l}\text { Rows and tufts on D and P; tufts } \\
\text { on most } \mathrm{C}, \mathrm{M}, \mathrm{I}\end{array}$ & $\begin{array}{c}300- \\
2 . .000\end{array}$ & $\begin{array}{l}\text { Chemoreception and } \\
\text { mechanoreception }\end{array}$ \\
\hline Serrate setae & 4,5 & $\begin{array}{l}\text { Tuft on distal end of } \mathrm{P} \text { of } 4 \text { and } \\
5 \text { extending toward } \mathrm{D} \text {; rows on } \\
\mathrm{D} \text { of } 5\end{array}$ & $\begin{array}{l}1.000- \\
2.000\end{array}$ & $\begin{array}{l}\text { Chemoreception and } \\
\text { mechanoreception }\end{array}$ \\
\hline Hedgehog hairs & $2,3,5$ & $\begin{array}{l}\text { Row along cutting edge of claws } \\
\text { of } 2 \text { and } 3 \text {; ridge on D and cu- } \\
\text { ticular extension on P of } 5\end{array}$ & $100-2.000$ & $\begin{array}{l}\text { Chemoreception and } \\
\text { mechanoreception }\end{array}$ \\
\hline \multicolumn{5}{|l|}{ Peg Sensilla } \\
\hline - Type I & 1 & $\mathrm{D}$ and $\mathrm{P}$ & 70 & Mechanoreception \\
\hline - Type II & $1-5$ & $\begin{array}{l}\text { Widely distributed on all seg- } \\
\text { ments (except } D \text { of } 2-5) \text {. }\end{array}$ & 30 & Mechanoreception \\
\hline CAP organs & $1-5$ & $\begin{array}{l}\text { Distal side of I-M, M-C, and } \\
\text { C-P joints. }\end{array}$ & 20 & Mechanoreception \\
\hline
\end{tabular}

$\mathrm{D}=$ Dactylus P = Propodus $\mathrm{C}=$ Carpus; $\mathrm{M}=$ Merus $\mathrm{I}=$ Ischium; CAP organs = Cuticular Articulated Peg organs 


\subsection{Chordotonal Organs}

Chordotonal organs are structures that act as mechanosensory which is owned by two thirds of the members of the main class of arthropods, namely crustaceans and insects. This organ is a miniature of the combined sense organs, furthermore, its neurons can detect mechanical forces, such as sound waves. Chordotonal organs can also detect temperature and circadian clock (Taylor, 1967; Clarac and Vedel, 1975; Field and Matheson, 1998).

Cordonal organs are usually found around joints, especially in flexible limbs, for example in pereiopods (Clarac and Vedel, 1975) and antenna (Taylor, 1967; Vedel and Monnier, 1983; Bush and Laverack, 1982), where the nerves are channeled to the central network of the nervous system. The existence of motion and vibration that propagates on the bottom substrate of the water will basically stimulate the chordotonal organs. The special organ 'Myochordotonal Barth' is found in semi-terrestrial crabs, namely fiddler crabs and ghost crabs. Externally, chordotonal organs can be identified as thin-walled "windows" of the exoskeleton at each pereiopods. In ghost crabs, this sensory organ can receive sound waves that propagate through the substrate and air, while in fiddler crabs, this organ responds to the main sound vibrations found on the substrate. This chordotonal organ is thought to function in expanding the acoustic sensitivity of fiddler and ghost crabs, reaching frequencies above $300 \mathrm{~Hz}$. Therefore, these animals are considered capable of detecting sound wave frequencies above the average noise found in their habitat (Horch, 1971; Salmon et al., 1977; Taylor and Patek, 2010).

Interestingly, if the crab loses its legs from running away from predators or during fighting, the animal's acoustic sensitivity is reduced. This is because all of its walking legs contain sensory organs, however, a crab can still detect vibrations through the other leg. Crabs also show decreased acoustic sensitivity as they walk. This is what prevents these crabs from receiving sound vibrations that are generated as a result of their own movements (Salmon, 1984; Taylor and Patek, 2010).

In the waters, the chordotonal organs can easily detect the state of the environment, where the mechanical propagation that occurs in the waters will stimulate the sensory cells in the chordotonal organs. Chordotonal organs with sensory cells have been demonstrated to exist in the basal segment of the antenna flagellum of the hermit crab, Petrochirus (Taylor, 1967), as well as the antenna and antennule of lobsters (Hartman and Austin,
1972; Rossi-Durand and Vedel, 1982). The chordotonal organ is considered a highly sensitive system which is associated with the presence of an intersegmental junction of the antenna flagella and the antennula, such as that of the crayfish, Astacus (Masters et al., 1982; Bender et al., 1984).

Morphologically, the chordotonal organs are in the form of an elastic sheet, stretching at the joint and inserting the proximal and distal cuticle segments. Bipolar sensory neurons have cell bodies on these sheets (Laverack, 1987) and their axons are joined by sensory nerves that are connected to the central nervous system. The dendrites of these sensory cells end in the sensilla called scolopidia (Moulins, 1976). Chordotonal organ neurons are sensitive to changes in sheet length and tension produced by different motion and joint angular positions (Wiersma and Boettiger, 1959; Mendelson, 1963; Mill and Lowe, 1972). Burke (1954) was the first researcher to document the activity of the chordotonal organ PD (Propodite-dactylopodite) in Carcinus maenas.

Rossi-Durand and Vedel (1982) described the chordotonal organs in the antenna (Figure 1). Functional synergy between the $\mathrm{J} 2$ and $\mathrm{J} 3$ joints shown by the motoneuron innervating both extensor muscles and both flexor muscles is shown by the presence of specific proprioceptors connected with these two joints. This chordotonal organ, called CO J2-J3, is located between the extensor and flexor muscles, as well as in the dorsal part of the main sensory nerves (Rossi-Durand and Vedel, 1982). The chordotonal organs between the J2 and J3 joints are morphologically in the form of a broad elastic sheet, which is located proximal to the lateral side of the exoskeleton, in segment 2 (S2) (Figure 1) near the lateral condyle of the $\mathrm{J} 2$ joint. Expanding the $\mathrm{J} 2$ joint in an oblique direction, divides distally into two strands that end at the medial portion of the S3 segment near the medial condyle of the $\mathrm{J} 3$ joint. This thin strand connects the center of the sheet with the ventro-medial side of the flagella (Rossi-Durand and Vedel, 1982).

The chordotonal organs found at the pereiopod are described by Clarac (1990) (Figure 2). At the crustacean pereiopod, each joint has one chordotonal organ except that the I-M, M-C, and C-P joints have two organs. Anatomically, there were slight differences in the four group members of Decapoda, namely Astacura, Palinura, Anomura, and Brachyura. TC chordotonal organs are found only in Astacura. The basi-ischio-meropodite area is quite complex. True B-I joints are only found in Homarus and Astacus which have one chordotonal organ, these organs are not found in the other 
groups and the B-I joints do not function. The I-M joints in Homarus and Astacus have the ability to move large angles, and have two chordotonal organs, whereas in the other Decapod group the anterior I-M is associated with myochordotonal organs which delay the movement of the M-C joints (Clarac, 1990).

\subsection{Statocyst Organs}

In the life cycle of lobsters, after the eggs hatch, it begins with nauplisoma stage and the phyllosoma stage, where both stages are entirely planktonic. In the phyllosoma stage, the shape of the body, the cephalothorax part is flattened and widened. The development continues into a nectonic postlarva or puerulus stage with a compact and transparent cylindrical body shape (Phillips and Sastry, 1980; Booth and Phillips, 1994).

A statocyst is an organ that is shaped like a pocket-like membrane and is semi-transparent, filled with fluid, with chitinus hairs sticking out into the lumen, wherein there are statolithes inside. Statolithes are substances such as grains of sand that are totally encased in a dense mass, a mucoprotein matrix (Dunn, 1975), bound flexibly at the base of the cyst by secretions from tegumental glandular (Lang and Yonge, 1935).
The statocyst is a vital sensing organ for crustaceans, this organ has been found in lobsters since it was in the puerulus stage. As stated by Sekiguchi and Terazawa (1997), the extreme metamorphosis stage occurs during the first molting from the phyllosoma stage to the puerulus stage, which is the transition stage from planktonic to nectonic life. In the planktonic phase, nauplisoma and phyllosoma stages, they have not been able to detect sound waves. After entering the puerulus stage, lobsters end their wandering phase on the high seas and then migrate to the coast. It was at this time that Jeff et al. (2005) believed as the beginning where lobsters have phonoreceptor organs in the form of statocysts and chordotonal organs that play an important role in helping to find new habitats in coastal waters.

In general, statocysts in crustaceans are multi-functional organs among others; to determine the absolute position of the organism whose performance is coordinated with locomotor movement (Clark, 1896), to function as a vibration receptor system (Budelmann, 1988), to respond directly to the presence of mechanical stimulation, while the receptor hairs that are linked to help 'focus' the stimulus on nerve terminals (Budelmann, 1988; Beltz, 1995), and to function as a gravity
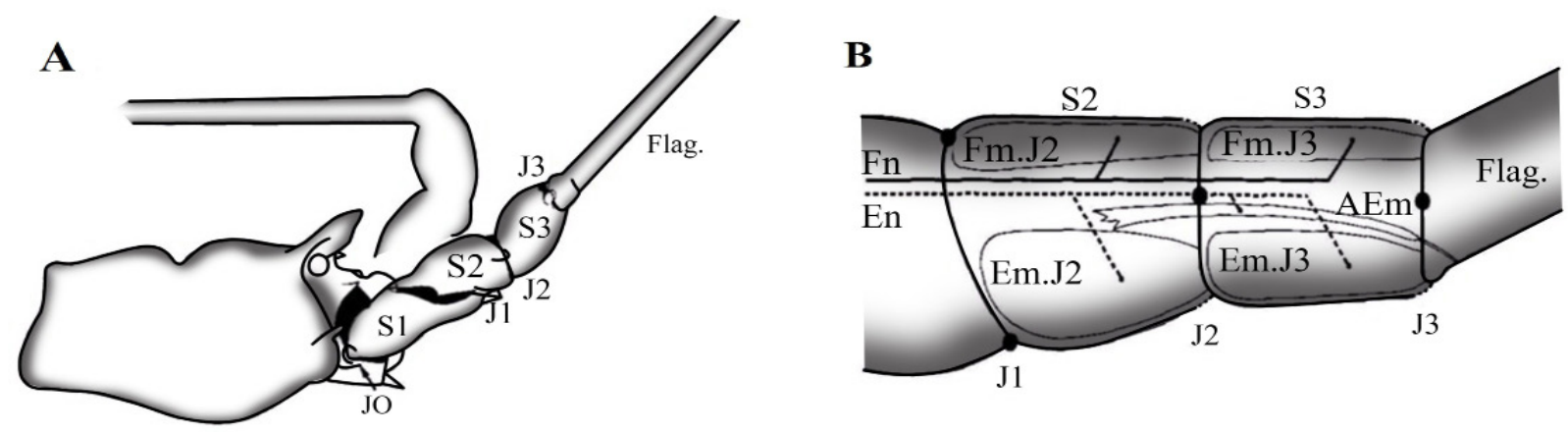

Figure 1. The chordotonal organ morphology of the Palinurus vulgaris antenna (refers to Rossi-Durand and Vedel, 1982). A Lateral view. S1, S2, S3 proximo-distal Segments; Flag. Flagellum. J0 (cephalothorax - SI), J1 (S1-S2), J2 (S2S3), J3 (S3-Flag.) proximo-distal Joints. B. Muscular organization of the J2 and J3 Joints. Fm. J2, Fm. J3 Flexor Muscles; Em. J2, Em. J3 Extensor Muscles; AEm Accessory Extensor Muscle; Fn Flexor Motor Nerve, En Extensor Motor Nerve.

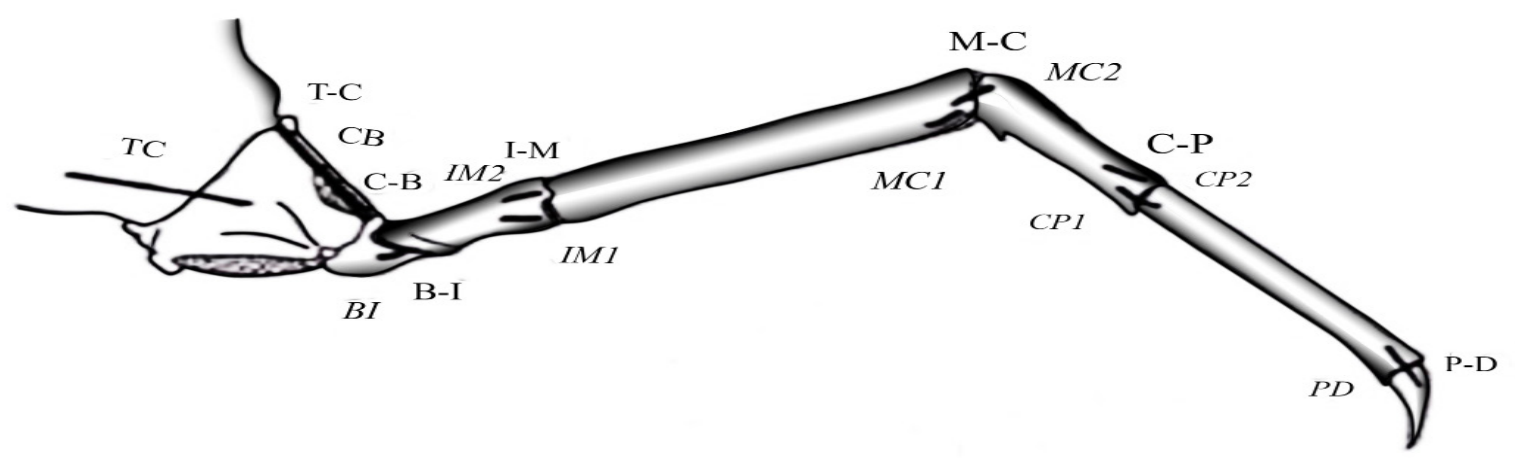

Figure 2. General organization of a crayfish leg with the different joints and the chordotonal organs (refers to Clarac, 1990). T-C Thoraco-coxopodite, C-B Coxo-basipodite, B-I: Basi-ischiopodite, I-M Ischio-meropodite, M-C Mero-carpopodite, C-P Carpo-propodite and P-D Pro-dactylopodite, and the chordotonal organs for each joint (TC, CB, BI, IM1, IM2, MC1, MC2, CP1, CP2, PD). 
receptor system and acoustic particle detector, so that this organ acts as a sense of hearing in the waters (Hawkins and Myrberg, 1983). Furthermore, Cohen (1955) stated that statocyst is sensitive to vibration. In lobsters, some statocyst nerve units are sensitive to vibrations contained in the base substrate, and in the hairs of the crayfish statolith receptors can respond to sound vibrations below a frequency of $200 \mathrm{~Hz}$ (Winn and Hazlett, 1962; Offutt, 1970). Statocysts mainly play a role in providing orientation cues that allow the animal to maintain its position in the water column. Several researchers have shown that statocysts also function to detect low-frequency sound waves (Masters et al., 1982; Proper et al., 2001; Lovell et al., 2005).

Statocysts are also found in other aquatic organisms such as cephalopods except nautilus. The Auditory Evoked Potential study with electrodes placed near the statocyst, showed that longfin squid responds to sounds at frequencies between $30-500 \mathrm{~Hz}$. These organisms are most sensitive to frequencies between 100 and $300 \mathrm{~Hz}$ (Packard et al., 1990). Studies with the Auditory Brainstem Response technique have shown that oval squid and octopus are sensitive to sound waves, at a frequency of 400-1,500 Hz and 400-1,000 Hz, respectively (Kaifu et al., 2007; Kaifu et al., 2008; Hu et al., 2009), as well as shrimp (Palaemon serratus) at frequencies ranging from 100 to $3.000 \mathrm{~Hz}$ (Lovell et al., 2005).

In crustaceans, the statocyst form basically has a similar structure even though the species are different, but its location varies among others; there are those in the basal antenna segment of Decapods, uropods or telson on Mysids, and Isopods. The structure of the receptors is flexible, i.e., sensory hair with a cuticle with asymmetric basal joints that polarize the hair in a particular direction. The friction of the cuticle sensory hair with the overlying statolith structure stimulates three sensory cells that are mechanically connected to the cuticle hair (Stein, 1975; Takahata and Hisada, 1979). The number of cuticle hairs in each statocyst varied from three strands, in Isopod Cyathura, to about 400 in the Homarus Decapod. These cuticle hairs are generally arranged in two to four rows forming a crescent pattern, with the direction of polarization always pointing towards the center of the crescent (Sandeman and Okajima, 1972; Rose and Stokes, 1981).

In Jasus edwardsii puerulus, anatomically the statocyst is in the form of an open cavity, its position is located on the dorsal surface of the basal segment of the antenna (Figure 3). The cavity is oval in shape, its long axis is parallel to the antenna and this cavity gets narrower as it points forward. The puerulus exoskeleton is very thin in texture except around the statocyst cavity, and the cuticle hangs in the anterior part of the cavity.
In this organ there are two rows of plumose-type setae that squeeze the cavity: the first row consists of about 16 setae measuring about $500 \mu \mathrm{m}$ with the base of the large setule and the other row consists of about 19 setae measuring about $300 \mu \mathrm{m}$ with the base of the small setule (Sekiguchi and Terazawa, 1997).

The statocyst cavity in the J. edwardsii puerulus contains hardened statolith grains, each grain measuring 50-60 $\mu \mathrm{m}$ (Sekiguchi and Terazawa, 1997). In contrast to that found in Decapods such as Astacidea and Brachyura (Silvey and Sandeman, 1976; Hertwig et al., 1991), in puerulus $J$. edwardsii statolith structures are not found as cemented substances that form a compact mass and do not have a mineral or crystalline core. There was no sensory hair in the cavity, and statoliths were not visible on the inner wall of the cavity (Sekiguchi and Terazawa, 1997).

During its growth, lobster statocyst at the puerulus stage actually undergoes morphological and physiological improvements. Cohen (1955) has conducted a morphological study on adult lobsters with a body weight of 800 grams, the statocyst was found to be 7 $\mathrm{mm}$ long, $4 \mathrm{~mm}$ wide, and $3 \mathrm{~mm}$ thick. The statocyst is located on the dorsal antenula wall. On the anterior back of the center there is a hole that opens out near the area of attachment.

The dorsal area in the basal segment of the antenula and the dorsal statochial wall has been removed to reveal the contents of the lumen (Figure 4). The anterior is facing upwards, while the lateral is on the right. There is a sensory basalt that curves into a crescent moon with four rows of hairs. The statolith mass is in contact with the three row structures on the inside. Medial fine hairs protrude horizontally into the interior of the lumen from the posterior region of the medial wall (Cohen, 1955). In the center of the cyst there, is a particle substance in the form of grains of sand, where each sand grain is securely attached en masse and forms a compact mass called a statolith. It is rare to find fragmented statoliths in which the parts are not attached to the bottom but are free to move in the lumen. A very important role in this system is the existence of a relatively constant relationship between single hairs and statoliths (Cohen, 1955).

The nerves originating from the brain to the statocyst are combined nerves, in addition to going to the statocyst, these nerves also go to the antenula (Figure 4). There is a nerve about $7 \mathrm{~mm}$ extending proximal from the outside of the ventral cyst wall and leading dorso-laterally to the main part of the antennular nerve, entering the brain dorsally (Cohen, 1955). Furthermore, Schmidt et al. (1992) shows the main nervous system found in the brain and the statocyst position of the $P$. argus (Figure 5). 
A

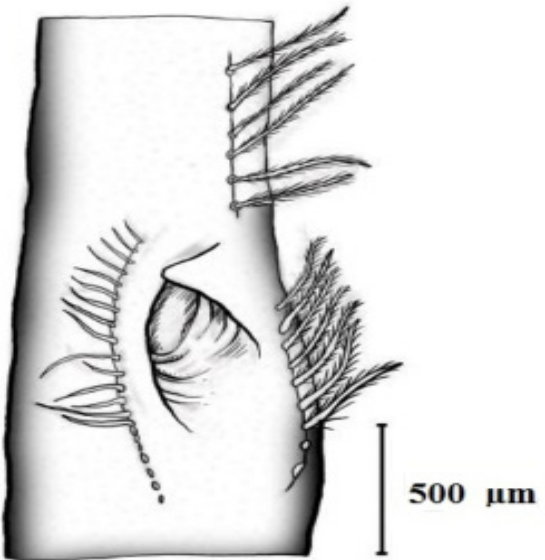

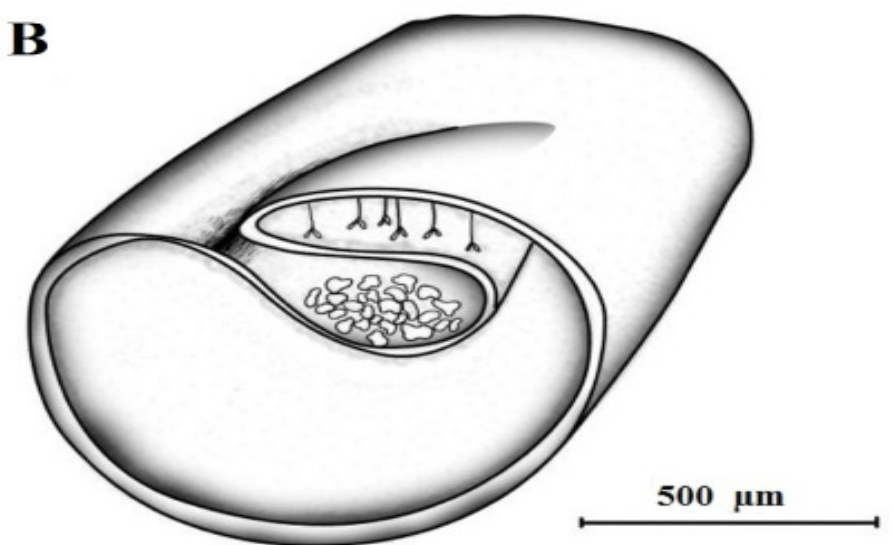

Figure 3. Statocyst image of the Jasus edwardsii puerulus antenna (refers to Sekiguchi and Terazawa, 1997). A. Schematic illustration of a dorsal view of the statocyst. Setae, with and without setule around a hollow-like slit (entrance). B. Schematic illustration of a sagittal view of the statocyst. The hardened statolite is located in the cavity.
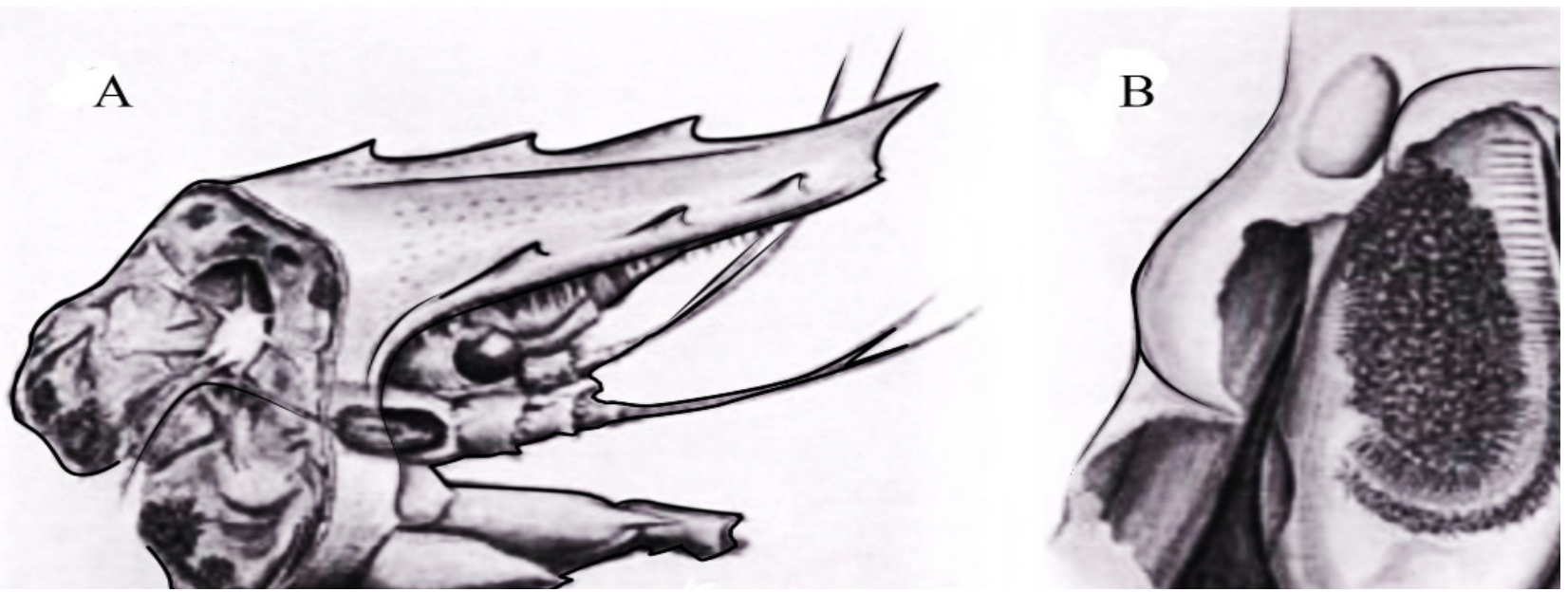

Figure 4. The image of Homarus americanus statocyst (refers to Cohen, 1955). A. Dissected anterior cephalo-thoracic part. The statocyst is found in the basal segment of the right antennule. The nerve seen extending from the brain to the statocyst is a joint of the statocyst with the antennular nerve. B. Drawing of the right statocyst in situ as seen from above.

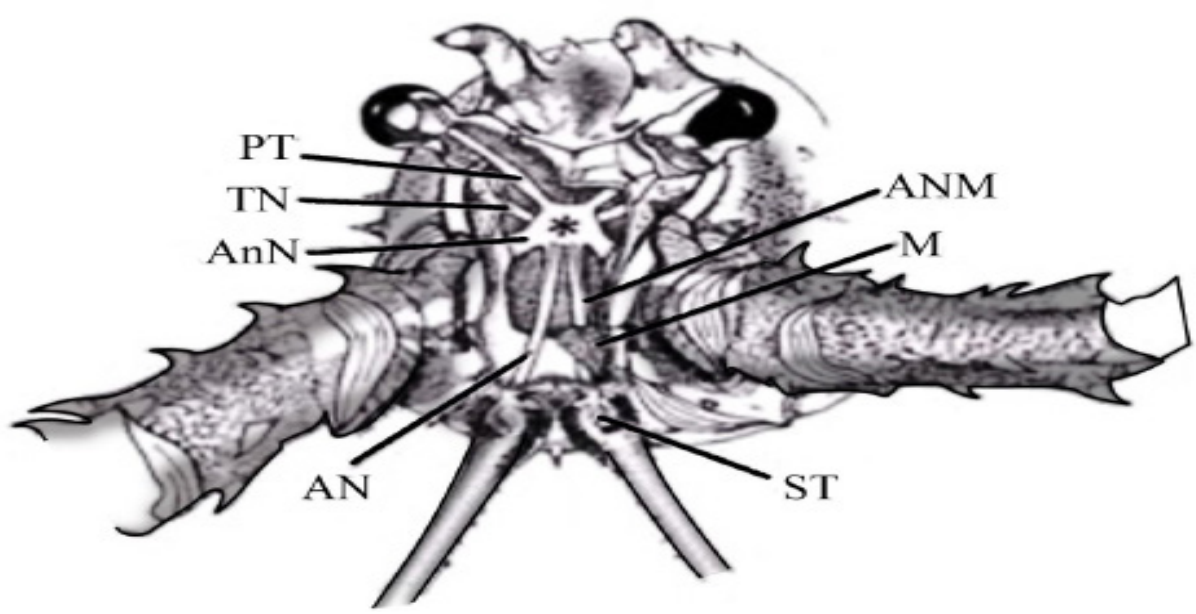

Figure 5. The position of the statocyst in the nerve and brain pathways in the anterior part of the head (refers to Schmidt et al., 1992). PT protocerebral tract, TN tegumentary nerve, AnN antennal nerve, ANM antennular motor nerve, $\mathrm{M}$ innervates muscles, AN antennular nerve, ST statocyst 
The presence of four main nerves connected to the brain are as follows: the protocerebral tract leads to the eye shaft, the tegumentary nerve goes to the head and thorax cuticle, the antennal nerve goes to the antenna, and the antenular nerve leads to the antenula (Figure 5). The antenular motor nerve points parallel to the antennular nerve and innervates the muscle at the base of the antenna. ST is a Statocyst (Schmidt et al., 1992).

The determination of statoliths as cells that are sensitive to stimulation is very important. In the lobsters of the genus Homarus the receptor cells are bound flexibly to the floor of the cyst in such a way that they can only move very little. The determination of statoliths as receptor cells that are sensitive to stimuli is constant for certain types of stimuli. So it is agreed that this organ provides a response in relation to the interpretation of the presence of the signal. This situation is different from that of the genus Panulirus (Cohen et al., 1953) where statoliths are more free to move within the cyst. In this case, the relationship between statoliths and receptors is not constant. There is sensitivity but lack of accuracy in such a system structure. In the genus Panulirus, eyes may have a more dominant function than statocysts (Cohen, 1955).

\section{Conclusion}

It can be concluded that: lobsters (Panulirus spp.) have senses capable in detecting sound waves from the surrounding environment, this ability is owned by lobsters since they were in the postlarva or puerulus stage. Anatomically, the organs that act as the sense of hearing in lobsters are receptors on the body surface, chordotonal organs, and statocyst organs.

Understanding the knowledge of receptor sensory organs and auditory behavior in lobster resources can be used as a basis for the development of sound wave-based attractor designs. This equipment has the opportunity to be applied in the utilization of lobster resources, as well as for fish.

The next study is to carry out a physiological analysis of how the mechanism of the sense of hearing in the puerulus can capture sound waves from its environment. Because at this stage, lobsters already have organs that play an important role in capturing sound waves and use them to find locations in coastal waters to subsequently settle in these waters. Scientifically, this stage is very important to serve as the basis for further studies on the use of underwater sound which is the result of recording natural sounds of coastal waters, as a sound source capable of acting as an attractor or posi- tive phonotactic for puerulus.

\section{Acknowledgement}

On my personal behalf, I would like to express my deepest gratitude to my Senior Brother Evron Asrial (Rector of the University of 45 Mataram, Indonesia), as the second writer, who has given a lot of input to the author, he passed away a few days ago in while this manuscript is in the process of being refined. For this reason, the author fully dedicates this manuscript as a form of tribute to my beloved brother Evron Asrial. My gratitude also goes to the Chancellor of the Hang Tuah University Surabaya, the Dean of the Faculty of Engineering and Marine Sciences, as well as the Head of the Fisheries Science Study Program who has entrusted me to teach and convey knowledge through the Aquatic Animal Physiology Course to students, whose content is about Pisces Physiology and Crustacean Physiology. And also thanks to all authors who have contributed voluntarily.

\section{Authors' Contributions}

The author has made excellent contributions, from designing the draft manuscript to perfecting the final draft of the manuscript before sending it back to the journal manager. Hari Subagio; contributed to the study of physiological and behavior aspects of lobsters (Panulirus spp.) and crustaceans. Evron Asrial; contributed to the study of lobster resource management aspects. Yusnaini; contributed to the study of the biological aspects of lobster development. Nurul Rosana; contributed to the study of sound wave-based attractor equipment in capture fisheries. Gatut Bintoro; contributed to the study of the technical aspects of catching lobster seeds. Nuhman; contributing to the study of the osmoregulation and behavior aspects of shrimps. I Made Kawan; contributed to the study of the reproductive and growth aspects of crustacean larvae.

\section{Conflict of Interest}

We, the authors of this manuscript, are fully aware that this article was not prepared commercially and we firmly believe that there will be no conflict between us regarding this paper in the future.

\section{Funding Information}

The drafting project of this manuscript is not fully supported by any funding party, while all forms of fees used are purely from the authors as a form of agreement between us. 


\section{References}

Atema, J., \& Voigt, R. (1995). Behavior and sensory biology. In J. R. Factor (Ed.), The biology of the lobster, Homarus americanus. (pp. 313-348). New York: Academic Press.

Au, W. W. L., \& Banks, K. (1998). The acoustics of the snapping shrimp Synalpheus parneomeris in Kaneohe Bay. The Journal of Acoustical Society of America, 103:41-47.

Ball, E. E., \& Cowan, A. N. (1977). Ultrastructure of the antennal sensilla of Acetes (Crustacea, Decapoda, Natantia, Sergestidae). Philosophical Transactions of the Royal Society B Biological Sciences, 277:429-456.

Beltz, B. (1995). Neurobiology and neuroendocrinology. In J. R. Factor (Ed.), The Biology of the Lobster, Homarus americanus. (pp. 267-90). New York: Academic Press.

Bender, M., Gnatzy, W., \& Tautz, J. (1984). The antennal feathered hairs in the crayfish: a non-innervated stimulus transmitting system. Journal of Comparative Physiology A, 154:45-47.

Booth, J. D., \& Phillips, B. F. (1994). Early life history of spiny lobster. Crustaceana, 66(3):271-294.

Breithaupt, T., \& Tautz, J. (1990). The sensitivity of crayfish mechanoreceptors to hydrodynamic and acoustic stimuli. In K. Wiese, W. D. Krenz, J. Tautz, H. Reichert, \& B. Mulloney (Ed.), Frontiers in crustacean neurobiology. (pp. 114-120). Basel: Birkhäuser.

Budelmann, B. U. (1988). Morphological diversity of equilibrium receptor systems in aquatic invertebrates. In J. Atema, R. R. Fay, A. N. Popper, \& W. N. Tavolga (Ed.), Sensory biology of aquatic animals. (pp. 757-782). New York: Springer-Verlag.

Budelmann, B. U. (1989). Hydrodynamic receptor systems in invertebrates. In S. Coombs, P. Gerner, \& H. Munz, (Ed.), The mechanosensory lateral line: neurobiology and evolution. (pp. 607631). New York: Springer-Verlag.

Budelmann, B. U. (1992). Hearing in crustacea. In D. B. Webster, R. R. Fay, A. N. Popper (Ed.), The evolutionary biology of hearing. (pp 131-139). New York: Springer-Verlag.
Burke, W. (1954). An organ for proprioception and vibration sense in Carcinus maenas. Journal of Experimental Biology, 31(1):126-137.

Bush, B. M. H., \& Laverack, M. S. (1982). Mechanoreception. In H. L. Atwood, \& D. C. Sandeman (Ed.), The biology of crustacea, Vol. 3 Neurobiology: structure and function. (pp. 399-468). New York: Academic Press.

Clarac, F. (1990). Proprioception from chordotonal organs in crustacean limbs. In K. Wiese, W. D. Krenz, J. Tautz, H. Reichert, \& B. Mulloney (Ed.), Frontiers in crustacean neurobiology. (pp. 262-270). Birkhäuser Verlag.

Clarac, F., \& Vedel, J. P. (1975). Proprioception by chordotonal and myochordotonal organs in the walking legs of the rock lobster Palinurus vulgaris. Marine Behaviour and Physiology, 3(3):157-165.

Clark, J. P. (1896). On the relation of the otocysts to equilibrium phenomena in Gelasimus pugilator and Platyonichus ocellatus. The Journal of Physiology, 19(4):327-343.

Cohen, M. J., \& Dijkgraaf, S. (1961). Mechanoreception. In T. H. Waterman (Ed.), Physiology of crustacea. (pp. 65-108). New York: Academic Press.

Cohen, M. J. (1955). The function of receptors in the statocyst of the lobster Homarus americanus. Journal of Physiology, 130(1):9-34.

Cohen, M. J., Katsuki, Y., \& Bullock, T. H. (1953) Oscillographic analysis of equilibrium receptors in crustacea. Experientia, 9:434-435.

De Lara, V. C., M. Butler, S. Hernández-Vázquez, S. G. del PróoC, \& Serviere-Zaragoza, E. (2005). Determination of preferred habitats of early benthic juvenile California spiny lobster, Panulirus interruptus, on the Pacific coast of Baja California Sur, Mexico. Marine and Freshwater Research, 56(7):1-9.

Denton, E. J., \& Gray, J. A. B. (1985). Lateral-line-like antenna of certain of the Penaeidea (Crustacea, Decapoda, Natantia). Proceedings of the Royal Society B, 226:249-261.

Derby, C. D. (1982). Structure and function of cuticular sensilla of the lobster Homarus Americanus. 
Subagio et al. / JIPK, 13(2):255-270

Journal of Crustacean Biology, 2(1):1-21.

Dunn, P. A. (1975). Anatomy and physiology of hair receptors in the statocyst of the crab, Scylla serrata. Thesis. Canberra: Australian National University.

Edmonds, N. J., Firmin, C. J., Goldsmith, D., Faulkner, R. C., \& Wood, D. T. (2016). A review of crustacean sensitivity to high amplitude underwater noise: data needs for effective risk assessment in relation to UK commercial species. Marine Pollution Bulletin, 108(1-2):5-11.

Evron, A., Rossadi, E., Hamid, Ichsan, M., Khasanah, R. I., Sulystyaningsih, N. D., Sumiwi, A. D., $\&$ Khalisah, N. (2020). Growth and population parameters of Panulirus penicillatus and Panulirus homarus in Labangka Tidal Waters, Indonesia. Jurnal Ilmiah Perikanan dan Kelautan. 12(2):214-223.

Factor, J. R. (1995). Biology of the lobster Homarus americanus. (pp. 545). San Diego: Academic Press.

Field, L. H., \& Matheson, T. (1998). Chordotonal organs of insects. Advances in Insect Physiology, $27: 1-230$

George, R. W., \& Main, A. R. (1967). The evolution of spiny lobsters (Palinuridae): a study of evolution in the marine environment. Evolution, 21(4):803-20.

Gilchrist, J. D. F. (1913). A free-swimming nauplioid stage in Palinurus. Zoological Journal of the Linnean Society, 32(216):225-231.

Goodall, C., Chapman, C., \& Neil, D. (1990). The acoustic response threshold of the Norway lobster, Nephrops norvegicus (L.) in a free sound field. In K. Wiese, W. D. Krenz, J. Tautz, H. Reichert, \& B. Mulloney (Ed.), Frontiers in Crustacean Neurobiology. (pp. 106-113). Basel, Boston, Berlin: Birkhauser Verlag.

Hartman, H. B., \& Austin, W. D. (1972). Proprioceptor organs in the antenna of decapod crustacea. Journal of Comparative Physiology, 81:187202.

Hawkins, A. D., \& Myrberg, A. A. (1983). Hearing and sound communication under water. In B. Lewis (Ed.), Bio-acoustics, a comparative approach. (pp. 347-405). London: Academic Press.

Henninger, H. P. \& Watson, W. H. (2005). Mechanisms underlying the production of carapace vibrations and associated waterborne sounds in the American lobster, Homarus americanus. Journal of Experimental Biology, 208(17):34213429 .

Herrnkind, W. F. \& Butler, M. J. (1994). Settlement of spiny lobster, Panulirus argus (Latreille, 1804) in Florida-Pattern without predictability. Crustaceana, 67(1):46-64.

Hertwig, I., Schneider, H., \& Hentschel, J. (1991). Light-and electron-microscopic analysis of the statocyst of the American crayfish Orconectes limosus (Crustacea, Decapoda). Zoomorphology, 110:189-202.

Horch, K. (1971). An organ for hearing and vibration sense in the ghost crab Ocypode. Zeitschrift für vergleichende Physiologie, 73:1-21.

Horch, K. (1975). The acoustic behavior of the ghost crab Ocypode cordimana Latreille, 1818 (Decapoda, Brachyura). Crustaceana, 29(2):193205.

Hu, M. Y., Yan, H. Y., Chung, W. S., Shiao, J. C., \& Hwang, P. P. (2009). Acoustically evoked potentials in two cephalopods inferred using the auditory brainstem response (ABR) approach. Comparative Biochemistry and Physiology Part A: Molecular and Integrative Physiology, 153(3):278-283.

Husni, S., Yusuf, M., Nursan, M., \& Utama, A. F. F. R. (2021). Socio-economic losses of small fishermen after lobster seeding banning policy (case study in Batu Nampar Selatan Village, East Lombok Regency). Jurnal Biologi Tropis, 21(1):112-119.

Indonesian Government. (2016). Larangan penangkapan dan/atau pengeluaran lobster (Panulirus spp.), kepiting (Scylla spp.), dan rajungan (Portunus spp.) dari wilayah Negara Republik Indonesia. Peraturan Menteri Kelautan dan Perikanan Republik Indonesia Nomor 56/Permen-KP/2016. Jakarta: Kementerian Kelautan dan Perikanan.

Indonesian Government. (2020). Pengelolaan lobster (Panulirus spp.), kepiting (Scylla spp.), dan rajungan (Portunus spp.) di Wilayah Negara Re- 
publik Indonesia. Peraturan Menteri Kelautan Dan Perikanan Republik Indonesia Nomor 12/ Permen-KP/2020. Jakarta: Kementerian Kelautan dan Perikanan.

Jeffs A. G., Montgomery, J. C., \& Tindle, C. T. (2005). How do spiny lobster post-larvae find the coast? New Zealand Journal of Marine and Freshwater Research, 39(3):605-617.

Jeffs, A. G., Diebel, C. E., \& Hooker, S. H. (1997). Arrangement and significance of pinnate sensory setae on the antenna of the puerulus and post-puerulus of the spiny lobster, Jasus edwardsii (Palinuridae). Marine and Freshwater Research, 48(8):681-686.

Jézéquel, Y., Bonnel, J., Coston-Guarini, J., \& Chauvaud, L. (2019). Revisiting the bioacoustics of European spiny lobsters Palinurus elephas: comparison of antennal rasps in tanks and in situ. Marine Ecology Progress Series, 615:143157.

Jézéquel, Y., Chauvaud, L., \& Bonnel, J. (2020). Spiny lobster sounds can be detectable over kilometers underwater. Scientific Reports, 10:7943.

Jones, C. M. (2010). Tropical rock lobster aquaculture development in Vietnam, Indonesia and Australia. Journal of the Marine Biological Association of India, 52(2):304-315.

Jones, C. M. (2018). Progress and obstacles in establishing rock lobster aquaculture in Indonesia. Bulletin of Marine Science, 94(3):1223-1233.

Jones, C. M., Diedrich, A., Irvin, S., Giri, A., Haryanti, Petersen, E., Priyambodo, B., Ruello, N., \& Sudewi. (2020). Research for development of lobster growout technology in Indonesia. ACIAR Project FIS/2014/059.

Jones, C. M., Anh, T. L., \& Priyambodo, B. (2019). Lobster aquaculture development in Vietnam and Indonesia. In E.V. Radhakrishnan, B.F. Phillips, Achamveetil, \& Gopalakrishnan (Eds.), Lobsters: biology, fisheries and aquaculture. (pp. 541-571). Singapore: Springer Nature.

Kaifu, K., Akamatsu, T., \& Segawa, S. (2008). Underwater sound detection by cephalopod statocyst. Fisheries Science, 74(4):781-786.

Kaifu, K., Segawa, S., \& Tsuchiya, K. (2007). Behav- ioral responses to underwater sound in the small benthic octopus Octopus ocellatus. The Journal of the Marine Acoustics Society of Japan, 34(4):266-273.

Lang, D., \& Yonge, C. M. (1935). The function of the tegmental glands in the statocyst of Homarus vulgaris. Journal of the Marine Biological Association of the United Kingdom, 20:333-339.

Laverack, M. S. (1962). Response of cuticular sense organs of the lobster, Homarus vulgaris (Crustacea). I. Hairpeg organs as water current receptors. Comparative Biochemistry and Physiology, 5(4):319-325.

Laverack, M. S. (1963). Response of cuticular sense organs of the lobster, Homarus vulgaris (Crustacea), III. Activity invoked in sense organs of the carapace. Comparative Biochemistry and Physiology, 10(4):261-272.

Laverack, M. S. (1987). The nervous system of the Crustacea, with special reference to the organisation of the sensory system. In M. A. Ali (Ed.), Nervous systems in invertebrates. (pp. 323-352). Boston: Springer.

Lovell, J. M., Findlay, M. M., Moate, R. M., \& Yan, H. Y. (2005). The hearing abilities of the prawn Palaemon serratus. Comparative Biochemistry and Physiology Part A: Molecular \& Integrative Physiology, 140(1):89-100.

Macmillan, D. L., Phillips, B. F., \& Coyne, J. A. (1992). Further observations on the antennal receptors of rock lobsters and their possible involvement in puerulus stage navigation. Marine Behaviour and Physiology, 19(3):211-225.

Masters, W. M., Bernhard, A., Tautz, J., \& Mark1, H. (1982). A new type of water vibration receptor on the crayfish antenna, II. Model of receptor function. Journal of Comparative Physiology, 149:409-422.

Mellon, D. (1963). Electrical responses from dually innervated tactile receptors on the thorax of the crayfish. Journal of Experimental Biology, 40(1):137-148.

Mendelson, M. (1963). Some factors in the activation of crab movement receptors. Journal of Experimental Biology, 40(1):157-169. 
Meyer-Rochow, V. B., \& Penrose, J. D. (1974). Sound and sound emission apparatus in puerulus and post-puerulus of the western rock lobster (Panulirus longipes). Journal of Experimental Zoology, 189(2):283-289.

Meyer-Rochow, V. B., \& Penrose, J. D. (1976). Sound production by the western rock lobster Panulirus longipes (Milne Edwards). Journal of Experimental Marine Biology and Ecology, 23(2):191-209.

Meyer-Rochow, V. B., Penrose, J. D., Oldfield, B. P., \& Bailey, W. J. (1982). Phonoresponses in the rock lobster Panulirus Iongipes (Milne Edwards). Behavioral and Neural Biology, 34(3):331-336.

Mill, P. J., \& Lowe, D. A. (1972). An analysis of the types of sensory unit present in the PD proprioceptor of Decapoda crustaceans. Journal of Experimental Biology, 56(2):509-525.

Mooney, T. A., Hanlon, R. T., Christensen-Dalsgaard, J., Madsen, P. T., Ketten, D. R., \& Nachtigall, P. E. (2010). Sound detection by the longfin squid (Loligo pealeii) studied with auditory evoked potentials: sensitivity to low-frequency particle motion and not pressure. Journal of Experimental Biology, 213(21):3748-3759.

Moulins, M. (1976). Ultrastructure of chordotonal organ. In P.J. Mill (Ed.), Structure and function of proprioceptors in the invertebrates. (pp. 387422). London: Chapman and Hall.

Oakley, J. K., \& Macmillan, D. L. (1980). The morphology and physiology of CAP organs in Jasus novaehollandiae (crustacea, decapoda, reptania, macrura). Marine Behaviour and Physiology, 7(3):233-247.

Offutt, G. C. (1970). Acoustic stimulus perception by the American lobster Homarus americanus (Decapoda). Experientia, 26:1276-1278.

Packard, A., Karlsen, H. E., \& Sand, O. (1990). Low frequency hearing in cephalopods. Journal of Comparative Physiology A, 166(4):501-505.

Patek, S. N. (2001). Spiny lobsters stick and slip to make sound. Nature, 411(6834):153-154.

Patek, S. N. (2002). Squeaking with a sliding joint: mechanics and motor control of sound production in palinurid lobsters. Journal of Experimental
Biology, 205(16):2375-2385.

Phillips, B. F., \& Sastry, A. N. (1980). Larval ecology. In J. Cobb, \& B.F. Phillips (Ed.), The biology and management of lobsters. (pp. 11-57). New York: Academic Press.

Phillips, B. F., \& Macmillan, D. L. (1987). Antennal receptors in puerulus and postpuerulus stages of the rock lobster Panulirus cygnus (Decapoda: Palinuridae) and their potential role in puerulus navigation. Journal of Crustacean Biology, 7(1):122-135.

Phillips, B. F. (2006). Lobsters: biology, management, aquaculture, and fisheries ( $\left.2^{\text {nd }} \mathrm{Ed}\right)$. New Jersey: Wiley Blackwell.

Phillips, B. F., Melville-Smith, R., \& Cheng, Y. W. (2003). Estimating the effects of removing Panulirus cygnus pueruli on the fishery stock. Fisheries Research, 65(1-3):89-101.

Popper, A. N., Salmon, M., \& Horch, K. W. (2001). Acoustic detection and communication by decapod crustaceans. Journal of Comparative Physiology A: Sensory, Neural, and Behavioral Physiology, 187(2):83-89.

Priyambodo, B., Jones, C. M., \& Sammut, J. (2020). Assessment of the lobster puerulus (Panulirus homarus and Panulirus ornatus, Decapoda: Palinuridae) resource of Indonesia and its potential for sustainable harvest for aquaculture. Aquaculture, 528.

Priyambodo, B., \& Sarifin. (2009). Lobster aquaculture industry in eastern Indonesia: Present status and prospects. In K. C. William (Ed.), Spiny lobster aquaculture in the Asia-Pacific region. (pp. 3645). Paper presented at Proceedings of an International Symposium, Nha Trang, Vietnam. Canberra: Australian Centre for International Agricultural Research.

Priyambodo, B., \& Jaya, S. (2009). Lobster aquaculture in eastern Indonesia, Part 1. St Louis: global aquaculture alliance.

Rosana, N., Sofijanto, M., \& Suryadhi. (2019). Assitence on the use of sound wave attractor to increase fishermen's number of catches Bulak district Surabaya. International Journal of Advanced Research, 7(8):324-327. 
Rosana, N., Rifandi, S., Suryadhi, \& Sofijanto, M. A. (2018a). Pemanggil ikan berbasis gelombang suara untuk nelayan jaring insang. Surabaya: Hang Tuah University Press.

Rosana, N., Suryadhi, \& Rifandi, S. (2018b). Design and trial test of fish caller device "piknet" for gillnet. Marine Fisheries, 9(2):199-207.

Rose, R. D., \& Stokes, D. R. (1981). A crustacean statocyst with only three hairs: light and scanning microscopy. Journal of Morphology, 169(1):2128.

Rossi-Durand, C., \& Vedel, J. P. (1982). Antennal proprioception in the rock lobster Palinurus vulgaris: Anatomy and physiology of a bi-articular chordotonal organ. Journal of Comparative Physiology, 145:505-516.

Salmon, M., Horch, K., \& Hyatt, G. W. (1977). Barth's myochordotonal organ as a receptor for auditory and vibrational stimuli in fiddler crabs (Uca pugilator and U. minax). Marine Behaviour and Physiology, 4(3):187-194.

Salmon, M. (1984). Acoustic "calling" by fiddler and ghost crabs. Australian Museum Memoir, $18(5): 63-76$.

Salmon, M., \& Atsaides, S. P. (1968). Visual and acoustical signalling during courtship by fiddler crabs (Genus Uca). American Zoologist, 8(3):623639.

Sandeman, D. C., \& Okajima, A. (1972). Statocyst-induced eye movements in the crab Scylla serrata. I. The sensory input from the statocyst. Journal of Experimental Biology, 57(1):187-204.

Schmidt, M., Van Ekeris, L., \& Ache, B. W. (1992). Antennular projections to the midbrain of the spiny lobster. I. Sensory innervation of the lateral and medial antennular neuropils. Journal of Comparative Neurology. 318:277-290.

Schmitz, B. (2002). Sound production in crustacea with special reference to the Alpheidae. In K. Wiese (Ed.), The crustacean nervous system (pp. 536547). Berlin, Heidelberg: Springer.

Schone, H., \& Steinbrecht, R. A. (1968). Fine structure of statocyst receptor of Astacus fluviatilis, $\mathrm{Na}$ ture, 220:184-186.
Sekiguchi, H., \& Terazawa, T. (1997). Statocyst of Jasus edwardsii pueruli (Crustacea, Palinuridae), with a review of crustacean statocysts. Marine \& Freshwater Research, 48(8):715-719.

Silvey, G. E., \& Sandeman, D. C. (1976). Integration between statocyst sensory neurons and oculomotor neurons in the crab Scylla serrata. 4. Integration phase lags and conjugate eye movements. Journal of Comparative Physiology, 108:67-73.

Smith, G. G., Salmon, M., Kenway, M., \& Hall, M. R. (2009). Description of the larval morphology of captive reared Panulirus ornatus spiny lobsters, benchmarked against wild-caught specimens. Aquaculture, 295(1-2):76-88.

Smith, K. N., \& Herrnkind, W. F. (1992). Predation on early juvenile spiny lobsters Panulirus argus (Latreille): influence of size and shelter. Journal of Experimental Marine Biology and Ecology, 157(1):3-18.

Solon, M. H., \& Cobb, J. S. (1980). The external morphology and distribution of cuticular hair organs on the claws of the American lobster, Homarus americanus (Milne-Edwards). Journal of Experimental Marine Biology and Ecology, 48(3):205-215.

Stein, A. (1975). Attainment of positional information in the crayfish statocyst. Fortschr Zoology, 23(1):109-119.

Suastika, M., Sukadi, F., \& Surahman, A. (2008). Studi kelayakan: meningkatkan pembesaran dan nutrisi lobster di Nusa Tenggara Barat. ACIAR Smallholder Agribusiness Development Initiative (SADI) Report. Canberra: ACIAR.

Susanti, E, N., Oktaviani, R., Hartoyo, S., \& Priyarsono, D. S. (2017). Efisiensi teknis usaha pembesaran lobster di Pulau Lombok Nusa Tenggara Barat. Jurnal Manajemen \& Agribisnis, 14(3):230239.

Takahata, M., \& Hisada, M. (1979). Functional polarization of statocyst receptors in the crayfish Procambarus clarkia Girard. Journal of Comparative Physiology, 130:201-207.

Tautz, J., Masters, W. M., Aicher, B., \& Markl, H. (1981). A new type of water vibration receptor 
on the crayfish antenna I. Sensory physiology. Journal of Comparative Physiology, 144:533541.

Tautz, J., \& Sandeman, D. C. (1980). The detection of waterborne vibration by sensory hairs on the chelae of the crayfish. Journal of Experimental Biology, 88(1):351-356.

Taylor, J. R. A., \& Patek, S. N. (2010). Crustacean seismic communication: Heard by not present? In C. E. O'Connell-Rodwell (Ed.), The use of vibrations in communication: properties, mechanisms and function across taxa. (pp. 9-23). India: Transworld Research Network.

Taylor, R. C. (1967). Functional properties of the chordotonal organ in the antennal flagellum of a hermit crab. Comparative Biochemistry and Physiology, 20(3):719-729.

Tazaki, K., \& Ohnishi, M. (1974). Responses from the tactile receptors in the antenna of the spiny lobster Panulirus japonicus. Comparative Biochemistry and Physiology Part A: Physiology, 47(4):1323-1327.

Tazaki, K. (1977). Nervous responses from mechanosensory hairs on the antennal flagellum in the lobster, Homarus americanus (L.). Marine Behaviour and Physiology, 5(1):1-18.

Thao, N. T. K. (2012). Opportunities and challenges in lobster marine aquaculture in Vietnam: The case of Nha Trang Bay. Thesis. Norway: University of Tromsø.

Vedel, I. P. (1985). Cuticular mechanoreception in the antennal flagellum of the rock lobster Palinurus vulgaris. Comparative Biochemistry and Physiology Part A: Physiology, 80(2):151-158.
Vedel, I. P., \& Clarac, F. (1976). Hydrodynamic sensitivity by cuticular organs in the rock lobster $\mathrm{Pa}$ linurus vulgaris. Morphological and physiological aspects. Marine Behaviour and Physiology, 3(4):235-251.

Vedel, J. P. \& Monnier, S. (1983). A new muscle receptor organ in the antenna of the rock Lobster Palinurus vulgaris: Mechanical, muscular and proprioceptive organization of the two proximal joints J0 and J1. Proceedings of the Royal Society B, 218:95-110.

Wiersma, C. A. G., \& Boettiger, E. (1959.) Unidirectional movement fibres from a proprioceptive organ of the crab Carcinus maenas. Journal of Experimental Biology, 36(1):102-112.

Wiese, K. (1976). Mechanoreceptors for near-field water displacements in the crayfish. Journal of Neurophysiol, 39:816-833.

Wiese, K., \& Marschall, H. P. (1990). Sensitivity to vibration and turbulence of water in context with schooling in antarctic krill Euphausia superba. In K. Wiese, W. O. Krenz, I. Tautz, H. Reichert, \& B. Mulloney (Ed.), Frontiers in crustacean neurobiology. (pp. 121-130). Berlin: Birkhauser Verlag.

Wilkens, L. A., Schmitz, B., \& Herrnkind, W. F. (1996). Antennal responses to hydrodynamic and tactile stimuli in the spiny lobster Panulirus argus. Neurobiology and Behavior, 191:187-198.

Winn, H. E., \& Hazlett, B. A. (1962). Sound production and associated behavior of Bermuda crustaceans (Panulirus, Gonodactylus, Alpheus, and Synalpheus). Crustaceana, 4(1):25-38.

Yusnaini. (2010). Perkembangan gonad, embrio dan larva lobster mutiara Panulirus ornatus. Makassar: Universitas Hasanuddin. 